\title{
Viver sem Deus e sem religião: a vida possível no ateísmo Living without God and religion: the possibility of atheism
}

\author{
Amauri Carlos Ferreira*
}

\begin{abstract}
Resumo
É possível viver no mundo sem Deus? É possível viver no mundo sem religião? O autor deste texto apresenta uma resposta afirmativa a essas indagações, fundamentando-a com as ideias de Bertrand Russell. Para o autor, quando a noção de viver bem é fundamentada na verdade provisória da ciência e contrária à vida proposta pela religião, os fiéis e os representantes eclesiásticos utilizam argumentos emocionais e falaciosos para postular a verdade da fé. Ele parte do pressuposto de que entre religião e ciência há conflitos, e não diálogos. Os conflitos se instauram na medida em que se percebe que a verdade humana é de processos, erros e acertos, não de certezas. A certeza da existência de Deus e do plano divino se justifica a partir de argumentos emocionais, que no mais das vezes levam a atos de crueldade e violência, como mostra a história. Para melhor compreender de que maneira os argumentos emocionais dos fiéis são legitimados, o autor recorre ao caso pessoal de Russell, quando o filósofo se viu impedido de lecionar na Faculdade de Filosofia Municipal de Nova York, nos anos 40 do século XX, devido a seu pensamento contrário à religião.
\end{abstract}

Palavras-chave: Ateísmo; Religião; Ciência; Fundamentalismo religioso.

\begin{abstract}
Is it possible to live without God? Is it possible to live without religion in the midst of faithful? Starting from the premise of conflict, not dialogue, between religion and science, the author uses the ideas of Bertrand Russell to support affirmative answers to these questions. When the notion of the good life is based on the provisional truth of science, rather than on religion, the faithful and the ecclesiastic representatives postulate the truth of faith using emotional and fallacious arguments. The conflict between religion and science arises with the perception that human truth is based on processes, errors and successes, not on certainties. The conviction of the existence of God and of a divine plan is justified by emotional arguments, in general accompanied by acts of cruelty and violence, as we know from history. In order to improve our understanding of how the faithful attempt to justify their emotional arguments, the author cites Russell's case, when the philosopher was prevented from teaching at the College of the City of New York (CCNY), in the 1940s due to his anti-religious ideas.
\end{abstract}

Key words: Atheism; Religion; Science; Religious fundamentalism.

Artigo recebido em 20 de agosto de 2010 e aprovado em 30 de setembro de 2010.

* Doutorado em Ciências da Religião pela Universidade Metodista de São Paulo, Brasil (2002). Atuação em Ética e Professor Adjunto III da Pontifícia Universidade Católica de Minas Gerais, Brasil. País de origem: Brasil. E-mail: mitolog@pucminas.br 
A questão da verdade de uma religião é uma coisa, mas a questão da utilidade é outra. Tenho a mesma convicção de que as religiões fazem mal, assim como acredito que não sejam verdadeiras. (Bertrand Russell).

\section{Introdução}

É possível viver sem Deus? É possível viver sem religião? Respostas divergentes a essas indagações sempre existiram: de um lado, os crentes negam essa possibilidade; de outro, os não crentes a afirmam.

Mas aqueles que optaram por uma resposta afirmativa a essas indagações tiveram que enfrentar, ao longo da história, críticas e ataques violentos, como se não fosse permitido discordar do já consagrado e estabelecido sobre Deus; como se o existir fizesse parte de alguma lei intocável, externa ao próprio indivíduo. Os defensores da fé sempre estiveram de plantão contra as supostas ameaças de pessoas que não professam o mesmo credo ou que são contrárias aos dogmas estabelecidos.

As religiões, de um modo geral, tentam reafirmar suas crenças frente a descobertas e pesquisas que nasceram de dúvidas em relação a verdades estabelecidas e legitimadas. Mas, em vez de se abrirem ao diálogo e à compreensão de ideias contrárias às suas, elas preferem defender suas convicções, ainda que seja com argumentos de natureza puramente emocional. Os defensores da fé desconsideram que a insurgência às normas faz parte da condição humana. É ela que torna possíveis os avanços no campo da moralidade e da ciência, propiciando um novo modo de explicação e compreensão do mundo. Foi assim no passado e tem sido assim no presente.

Para uma visão sem preconceitos dos que optam por uma resposta afirmativa às indagações propostas, torna-se necessário enveredar pelo território dos não crentes. Aí vamos reconhecer que os conflitos em torno da religião só ocorrem quando a vida é questionada em sua origem ou no modo de vivê-la e, também, quando o poder religioso é fragilizado pela compreensão racional do mundo. Afora isso, os crentes se beneficiam igualmente dos saberes e das descobertas científicas de ateus e não ateus. 
A relação entre ciência e religião tem sido marcada, no mundo contemporâneo, pelo conflito e pelo diálogo. Neste artigo, entretanto, parte-se do pressuposto de que só existe conflito entre os dois, devido à oposição entre o modo de conceberem o mundo: enquanto as religiões são portadoras de uma verdade divina baseada na fé, as ciências procuram uma verdade provisória demasiadamente humana. Considera-se ainda que a fundamentação contemporânea das religiões para comprovar a existência de Deus é invalidada pelo discurso de autoridade e pela emotividade dos crentes, que trazem a experiência religiosa individualizada como sendo o modelo coletivo e universal da práxis humana - atitude, aliás, que é uma repetição do passado. A defesa da existência de Deus, a fé das pessoas e o sentido das religiões não encontram fundamentação epistêmica sequer na legitimação da verdade religiosa.

Para evidenciar o conflito entre ciência e religião, bem como compreender os argumentos que levam a reações violentas contra os não crentes, escolhemos problematizar o modo de ver o mundo de um agnóstico ou ateu - Bertrand Russell - que viveu e se posicionou teoricamente sem a crença em Deus e sem religião.

\title{
1 Bertrand Russell : argumentos para uma vida sem Deus e sem religião
}

\begin{abstract}
Os cristãos garantem que sua fé conduz ao bem e que as outras conduzem ao mal. Eles dizem isso da fé comunista. Eu, o que digo é que toda a fé conduz ao mal. Podemos definir fé como uma firme convicção em alguma coisa de que não se tem nenhuma prova. Ali onde existe a prova, não se fala de fé. Não falamos de fé a respeito do fato de que dois e dois são quatro nem de que a terra é redonda. Só falamos de fé quando queremos substituir a prova pela emoção. (RUSSELL, 2000, p.42)
\end{abstract}

É inegável a contribuição de Bertrand Russell para o pensamento filosófico contemporâneo. Suas instigantes reflexões e seu modo de conceber o mundo fizeram dele uma referência no campo dos temas filosóficos e da matemática. Bem-humorado e rigoroso em seu método de viver e pensar, foi decidido ao desfrutar o mundo sem crer em Deus e sem professar uma religião. Como lembra Egner (2000, p.10), "durante toda sua vida, sustentou que o que faltava ao mundo era uma coisa fora de moda - uma atitude de amor e 
compaixão pela humanidade. Lamentavelmente os críticos omitiram as suas afirmações sobre o tema em desrespeitoso silêncio".

Não admira tal atitude por parte dos críticos, uma vez que bom número deles provavelmente estivesse vinculado aos círculos religiosos ou a crenças que os impediriam de considerar e respeitar o pensamento diverso. Este é o modo de fazer das religiões: pela via do silêncio, destituem o direito à fala, à defesa, omitem descobertas, escondem uma verdade evidente em troca de uma suposição.

Russell não se esquivava frente ao já estabelecido como verdadeiro. Em seu rigor científico, buscava empreender suas próprias descobertas. Ainda jovem, descobriu a crueldade das religiões e abandonou o cristianismo, religião em que fora criado. Seu pensamento atravessou o tempo, e seu ateísmo polido e bem-humorado nos leva ainda hoje a refletir sobre a possibilidade de uma vida sem Deus.

Uma de suas afirmações é que "a religião se baseia no medo" (RUSSELL, 2009a, p.40). Ao longo da história da cultura, há fatos suficientes para comprovar tal afirmativa, principalmente nos momentos em que houve discordância das verdades da fé. Isso é evidenciado tanto no campo da moral quanto no da ciência. Ao que tudo indica, há um falso discurso quando se tenta estabelecer o diálogo entre conhecimento religioso e científico. A religião se considera guardiã da vida, que pressupõe um ser supremo em sua criação. Tal pressuposição leva à crença na existência de Deus, em um plano divino para a vida. Para manter essa crença, a religião se utiliza do medo.

Foi no abandono da religião e, consequentemente, na ausência do medo que Bertrand Russell esculpiu no vivido sua compreensão de ser e de pertencer ao mundo, tendo tido a ousadia de expor publicamente, em 1927, argumentos para sua não crença no cristianismo. Russell iniciou sua exposição esclarecendo os ouvintes sobre o que é ser cristão:

Quando digo cristão, não quero dizer qualquer pessoa que tente viver de maneira decente de acordo com suas luzes. Penso que é preciso ter uma certa crença definida antes que se adquira o direito de se autodeterminar cristão. A palavra não tem o mesmo significado quando tinha na época de Santo Agostinho e Tomás de Aquino. Naquele tempo, se um homem afirmasse ser cristão, já se sabia o que ele queria dizer: ele aceitava. Aceitava todo um conjunto de credos definidos com muita precisão e 
acreditava em cada sílaba daquilo com toda força de suas convicções. (RUSSELL, 2009b, p.25-26)

A proposta de Russell era discutir a ausência de fundamentos na crença da religião cristã e, para isso, ele busca explicar o que é ser cristão. Segundo ele, o indivíduo que se autodenomina cristão deve necessariamente crer em Deus e na imortalidade. Além disso, deve acreditar na existência de Cristo. Partindo desse pressuposto, ele confessa o seu ateísmo: (...) "Não acredito em Deus e na imortalidade; e segundo, porque não penso que Cristo foi o melhor e mais sábio dos homens, apesar de atribuir a Ele um alto grau de excelência moral".

Assumir tal posição exigiu dele uma fundamentação teórica derivada de seu pensar filosófico. Seus argumentos provocaram evidente mal-estar nas autoridades eclesiásticas, que, não dispondo de elementos para uma refutação racional, recorreram a argumentos de autoridade ou emotivos. Tais argumentos são bastante comuns na história do pensamento ocidental, notadamente quando as autoridades eclesiásticas detêm o poder sobre as consciências - basta voltarmos ao contexto da Inquisição, ou à história de Giordano Bruno, Galileu, Darwin, entre outros, para lembrar de que maneira a religião costuma resolver seus conflitos.

Para evidenciar como os preconceitos teológicos reaparecem a cada momento em que o novo nas descobertas científicas se apresenta, Russell recorre a vários exemplos curiosos da ausência de reflexão por parte dos crentes e eclesiásticos. Um deles é o caso da vacina contra a varíola e seu processo de imunização, que, segundo Russell, trouxe protestos infundados, inaceitáveis do ponto de vista racional. Em seu livro Religião $e$ Ciência, ele lembra:

Um eclesiástico anglicano publicou um sermão no qual dizia que as pústulas sem dúvida eram decorrentes da inoculação pelo Diabo, e muitos ministros escoceses se uniram em um manifesto que afirmava que isso era uma tentativa de confundir um julgamento divino. Entretanto, o efeito na diminuição na taxa de mortalidade infantil ocasionada pela varíola foi tão notável que os terrores teológicos não conseguiram ultrapassar o medo da doença. No ano de 1885, diante do surto de varíola em Montreal, a parte católica da população resistiu à vacinação como apoio ao clero. Um dos padres afirmou 'Se somos afligidos pela varíola, é porque tivemos um carnaval no inverno passado e banqueteamos a 
carne, o que ofendeu ao senhor. Os padres Oblatos, cujas Igrejas estão situadas no centro do distrito infestado, continuaram a condenar a vacinação; os fiéis foram encorajados a confiar em exercícios de devoção de vários tipos; sob a sanção da hierarquia, uma grande procissão foi ordenada com um apelo solene à Virgem, e o uso do rosário foi definitivamente obrigatório. (RUSSELL, 2009b, p.75-76)

Outro exemplo citado por ele é o do uso da anestesia em partos para impedir o sofrimento da mulher. Em 1847, Simpson, ao recomendar tal prática, levou o clero a se lembrar da palavra bíblica que a mulher dará à luz com dores. Russell cita muitos outros casos históricos, mas esses em especial evidenciam o quanto a religião interfere em situações que ela desconhece, impedindo, às vezes, uma melhoria na qualidade de vida das pessoas. No mais das vezes, ela resolve os problemas formando pessoas destituídas de reflexão e de pensamento crítico: uma decisão embasada em princípios apenas religiosos gera a prática da maldade e da crueldade como medida de redenção.

Essa forma de solução de conflitos adotada ao longo da história pelas religiões parecia estar adormecida, mas ainda hoje o segmento religioso tem dificuldades em lidar com ideias que contrariem seu credo. A perseguição e a legitimação do poder religioso impedem o livre pensar e o viver com dignidade fora da esfera religiosa, inviabilizando o desenvolvimento da investigação científica.

Uma crença religiosa difere de uma teoria científica, ao alegar a incorporação plena de uma verdade eterna, ao passo que a ciência é sempre experimental, esperando que as modificações em suas teorias atuais, mais cedo ou mais tarde, sejam necessárias e ciente de que seu método é um daqueles logicamente incapaz de chegar a uma demonstração final e completa. (RUSSELL, 2009b, p.6)

Essa conclusão de Russell evidencia a diferença entre o discurso científico e o religioso. Para os crentes, a verdade vem de Deus, que fundamenta a sua concepção de mundo. Mas, será possível viver nesse mundo sem essa concepção oriunda de Deus? Russell aponta para a teoria da adaptação ao ambiente, mostrando que o mundo existe não para que os seres se adaptem a ele, mas o contrário. Em seus argumentos, o autor proclama a não existência de Deus: 
Os senhores sabem, é claro, que a Igreja Católica definiu como dogma o fato de a existência de Deus poder ser provada pela razão espontânea. Esse é um dogma um tanto curioso, mas é dos dogmas deles. Precisam introduzi-lo porque, em certa altura, os livres pensadores adotaram o hábito de dizer que existiam tais e tais argumentos por meio dos quais a pura e simples razão poderá concluir que Deus não existe, mas é claro que eles sabiam, por questão de fé, que Deus existe. (RUSSELL, 2009b, p.27)

Para atestar que a razão espontânea tem problemas, ele busca problematizar a causa primordial. Para ele, esse argumento perdeu sua vitalidade, uma vez que já existem estudos da ciência sobre a ideia de causa, que inviabilizam essa concepção. Segundo ele, a causa primordial é uma falácia, pois

Se tudo precisa ter uma causa, então também Deus deve ter uma causa. Se é possível que exista qualquer coisa sem causa, isso tanto pode ser o mundo, quanto Deus, de modo que não pode haver validação nesse argumento (...) A ideia de que as coisas precisam obrigatoriamente ter um início na verdade se deve à pobreza de nossa imaginação. (RUSSELL, 2009b, p.28)

Tal tipo de argumentação, convincente do ponto de vista lógico, estendeu-se também a outros argumentos questionados pela lógica de Russell - o da lei natural, o do plano divino, da moral a favor da divindade e o da reparação de injustiças. Nenhuma dessas propostas do cristianismo escapa à análise de Russel. Ele não consegue reconhecer contribuição alguma das religiões para que o indivíduo viva bem, de acordo com sua consciência, uma vez que a proposta religiosa está sedimentada numa falácia ou, como ele mesmo afirmou, numa mentira. Se Russell não acredita em Deus e nas religiões, ele acredita em quê? Na benevolência humana e na possibilidade de a ciência desvelar o que ainda não foi descoberto. Como grande filósofo e matemático, mostrou que é possível viver bem, mesmo quando a religião diz não; mostrou que é possível viver sem a crença em Deus, provando que ela é uma enorme falácia. Mostrou que o modo de viver de um ateu é como o de qualquer outro: o ateu pensa, expressa-se e age de acordo com sua consciência livre. A argumentação utilizada por Russell tinha um objetivo claro: ele acreditava que deveríamos pensar muito sobre aquilo que nos propomos e adotar uma reflexão 
cientificamente orientada sobre o que deveríamos fazer com nossas vidas (RUSSELL, 2009b, p.12).

É o rigor científico de Russell que dá credibilidade aos argumentos que usa quando afirma não ser cristão, mas um agnóstico e, especificamente, um ateu. É esse rigor que o fez afirmar com honestidade e dignidade:

penso no rigor filosófico em que se duvida da existência de objetos materiais e se sustenta que o mundo pode existir há apenas cinco minutos, eu devo me considerar um agnóstico; mas para todas as práticas, sou ateu. Não considero a existência do Deus cristão nem mais nem menos provável que a existência dos deuses do Olimpo ou de Vallalá. Para tomar outro exemplo: ninguém pode provar que não existe entre a Terra e Marte uma chaleira girando em órbita elíptica, mas ninguém o considera provável o bastante para ser levado em conta na prática. Eu considero o Deus cristão simplesmente improvável. (RUSSELL, 2000 p.59)

$\mathrm{Na}$ argumentação de Russell sobre a lei natural, destaca-se a concepção aceita na época de Newton em relação à gravidade: a de que "as pessoas observavam os planetas girando em torno do sol de acordo com a lei da gravidade, e pensavam que Deus tinha dado um comando a esses planetas para que se movessem daquela maneira específica, sendo por isso que o faziam" (RUSSELL, 2000, p.28). Para Russell, é com esse tipo de explicação conveniente e simples - ou seja, argumentos em torno da intervenção divina no funcionamento do mundo ou da lei como sendo criação da própria divindade - que a maioria dos religiosos fanáticos ainda concebem o mundo, mesmo após descobertas científicas como a interpretação de Einsten sobre a gravidade. Nesse raciocínio, Russell problematiza:

Por que Deus estabeleceu estas leis naturais e não outras? Se a resposta for por bel prazer e sem razão nenhuma, então descobre-se que existe alguma coisa que não está sujeita à lei, de modo que a linha da lei natural deve ser interrompida. Se for dito, como os teólogos mais ortodoxos dizem, que em todas as leis estabelecidas por Deus existe uma razão para que determinada lei fosse promulgada em detrimento de outras - tendo como razão, é claro, criar o melhor universo, apesar de ser impossível pensar assim ao examiná-lo - se houvesse uma razão para as leis que Deus estabeleceu, então o próprio Deus estaria sujeito à lei, de modo que não existe nenhuma vantagem em introduzir Deus como intermediário. 
$\mathrm{Na}$ verdade, tem-se uma lei alheia e anterior aos éditos divinos, e Deus não atende ao objetivo, porque Ele não é legislador supremo. (RUSSELL, 2009b, p.30).

Ao estabelecer esse argumento, Russell pontua que as ideias em relação à existência de Deus, tal como concebidas pelos crentes, não levam a uma compreensão plausível e sustentável do ponto de vista lógico e racional. E acrescenta: "no início, eram argumentos intelectuais rígidos, que incorporavam certas falácias bem definidas. Quando chegamos aos tempos modernos, elas se tornaram menos respeitadas intelectualmente e cada vez mais afetadas por um tipo de moralização vaga" (RUSSELL, 2009b, p.30).

Esse processo é admitido por Russell na argumentação a respeito do plano divino: “Tudo no mundo é feito para que consigamos viver nele, e se o mundo fosse mesmo que só um pouquinho diferente, não conseguiríamos habitá-1o" (RUSSELL, 2009a,p.30). Aqui, Russell recorre a Darwin no que se refere à base de adaptação das coisas viventes e à não evidência da divindade nesse processo. Ele estabelece o processo de aceitação das leis da ciência e parte da suposição de que o adotará em seus argumentos, o que, de uma certa forma, postula o conflito entre ciência e religião:

[...] quando se aceitam as leis comuns da ciência é necessário supor que a vida humana e a vida em geral neste planeta morrerão a seu tempo: tratase de um estágio de decadência do sistema solar; em um certo estágio dessa decadência, obtém-se o tipo de condições de temperatura, e assim por diante, que são adequadas ao protoplasma, sendo que existe vida, durante um curto espaço de tempo, na vida do sistema solar. Vê-se na lua o tipo de coisa que é a tendência da terra - transformar-se em algo morto, frio e sem vida.(RUSSELL, 2009b, p.31)

Esse talvez seja um dos argumentos de Russell que mais provocou mal-estar nos crentes em geral. Ao colocar a questão da vida em jogo, trazendo para seus argumentos a concepção da física e da biologia, ele aponta o que é central nas premissas em defesa da vida. Se voltarmos à história, perceberemos que o mundo vai bem até quando se questiona a finitude da vida, considerada pelas religiões um bem maior dado pela divindade. Russell, ao estabelecer tal arrazoado, mostra que as reações advindas dos segmentos religiosos são 
absurdas, pois que vão desde a condenação até ao processo de ridicularização de quem pensa diferente do que foi instituído.

Disseram-me que esse tipo de visão é deprimente, e as pessoas às vezes afirmam que, se acreditassem nisso, não seriam capazes de continuar vivendo. Não acreditem nisso; não passa de disparate. Ninguém realmente se preocupa com o que vai acontecer daqui a milhões de anos. Mesmo que achem que se preocupam muito com isso, na verdade estão se enganando. A preocupação delas diz respeito a algo muito mais mundano, ou pode tratar-se meramente de má digestão; mas ninguém fica seriamente infeliz por pensar que algo de ruim vai acontecer com este mundo daqui a milhões de anos. (RUSSELL, 2009b, p.31)

O mundo é inóspito, e os seres que nele vivem a ele se adaptam de acordo com suas necessidades. As religiões se apoiam em leis criadas pelos homens, leis morais que, pelas atitudes, destituem suas próprias origens. Nesse raciocínio, Russell remonta ao argumento de reparação das injustiças, invocando a religião em sua tentativa de prova da existência de Deus. "Diz-se que a existência de Deus é necessária para que haja justiça no mundo.” No entanto, o mundo continua injusto. Daí cria-se um mundo ainda sem critério de racionalidade. Russell é taxativo em relação às pessoas que acreditam em Deus. Para ele, os argumentos que elas utilizam para fundamentar sua crença não resistem a discussões intelectuais: são argumentos emotivos e cruéis, que tomam a parte como se fosse o todo. $\mathrm{O}$ que impulsiona as pessoas a acreditar em Deus, segundo ele (2009a, p.33-34), "não é absolutamente nenhum argumento intelectual. A maior parte acredita em Deus porque foi ensinada desde a primeira infância a fazê-lo, e essa é a razão principal".

Se o fator emocional é o motivo da fé, pode-se estender essa ausência de argumentos intelectuais a questões ligadas à própria vida e ao modo de viver das pessoas. Apegadas a esse fator, as autoridades religiosas, em períodos de legitimação de seu poder, cometeram muitas atrocidades.

O problema do argumento emocional é que, quando aliado ao de autoridade, ele é manipulador e se legitima em espaços que impedem o desenvolvimento da humanidade; dessa forma, o lento processo de mudança só ocorre quando há um enfrentamento ao já estabelecido. Segundo Russell (2009b, p.39), "em um exame do mundo como um todo, percebe-se que cada progresso, por menor que seja, cada melhoria no código penal, cada 
passo na direção do melhor tratamento das raças de cor, ou cada mitigação da escravidão, cada progresso moral que ocorreu no mundo só aconteceram em oposição às Igrejas organizadas do mundo".

Ao que tudo leva a supor, no pensamento de Russell, a questão religiosa configura a tentativa dos fiéis, principalmente cristãos, de pregar algo que não são capazes de cumprir e que se furtam a discutir. Tomando algumas palavras de Cristo - que ele considera interessantes como unidades de referência valorativa -, Russel aponta, de forma lapidar, a incapacidade dos cristãos de colocá-las em prática. Segundo ele, os cristãos dizem uma coisa e seguem outra. Vejamos:

\begin{abstract}
"Não resistas ao mal, mas, se alguém te ferir na tua face direita, apresenta-lhe também a outra..." "Não julgueis para que não sejais julgados"... "Dá a quem te pede, e não voltes as costas ao que deseja que lhe emprestes"... "Se queres ser perfeito, vai, vende o que tens, e dá-o aos pobres." Russell aponta essas máximas de Cristo, considerando-as importantes para o viver bem de um cristão que decidiu seguir a Cristo. Para ele, "são boas máximas, apesar de serem pouco difíceis de cumprir. Não professo que eu mesmo as cumpra; mas, afinal de contas, não é essa a mesma coisa que seria para um cristão". (RUSSELL, 2009b, p.35).
\end{abstract}

É no campo da moralidade que Russell aponta argumentos que, de certa forma, levam-no a uma vida boa fora da esfera religiosa. Ao questionar o caráter de Cristo e a crença no inferno, assinala:

$\mathrm{Eu}$, pessoalmente, não acredito que qualquer pessoa profundamente humana possa acreditar no castigo eterno, e em Cristo. Conforme descrito nos Evangelhos, certamente se acreditava no castigo eterno, sendo que podemos encontrar, repetidas vezes, uma fúria vingativa contra aqueles que se recusam a escutar pregações, mas que destoa da excelência superlativa. Assim Russell aponta o Evangelho e as falas de Cristo: "Serpentes, raça de víboras! Como escapareis da condenação do inferno?" "Aquele que disser alguma palavra contra o Espírito Santo não será perdoado. Nem neste mundo e nem no mundo futuro." "O filho de Deus enviará os seus anjos e eles tirarão do seu reino todos os escândalos e os que praticam a iniquidade, e lançá-los-á na fornalha de fogo. Ali haverá choro e ranger de dentes." "Apartai-vos de mim, malditos, para o fogo eterno. E estes irão para o suplício eterno." "Se tua mão ou o teu pé te fizer tropeçar, corta-o, lança-o de ti; melhor te é entrar na vida aleijado, ou coxo, do que, tendo duas mãos, ir para o inferno, para o fogo 
inextinguível onde o verme não morre e o fogo não se apaga". (RUSSELL, 2009b, p.36-37)

Russell aponta outras passagens, segundo ele de menor importância, mas intrigantes. Ao ressaltar partes do Evangelho para sustentar sua postura de não cristão, ele argumenta que a aceitação de uma religião implica concordar com seus princípios, e fundamenta sua discordância do cristianismo no fato de ser ele uma crença construída sob o signo do medo e em bases emocionais, que se contradizem na realidade da vida.

Todavia, como vive um ateu num mundo de crenças religiosas? Ao que indicam as obras e as atitudes de Russell, muito bem. Quando lhe perguntavam sobre seu racionalismo, declinava:

A toda hora me perguntam: o que o senhor, com seu frio racionalismo pode oferecer a quem busca salvação, que seja comparável ao conforto familiar e aconchegante de um bem protegido credo dogmático? A resposta a esta pergunta tem vários aspectos. Em primeiro lugar, eu não afirmo poder oferecer tanta felicidade quanto se pode obter por meio da bebida, das drogas ou da riqueza que se acumula roubando viúvas e órfãos. Não é a felicidade do converso individual o que me preocupa; é a felicidade da humanidade. (RUSSELL, 2000, p.44)

Em geral, o ateísmo de Russell vai se delineando em argumentos racionais e lúcidos trabalhados de forma lógica, o que irritou e tem irritado os que costumam usar argumentos emotivos ou a crueldade para com aqueles que não comungam o mesmo credo. Se o pensar de Bertrand Russell está focado na vida feliz, ou a vida que escolheu viver, numa perspectiva universal e não particular, seu objetivo é o da busca de verdades provisórias e racionais, fruto do fazer humano - nesse caso a ciência. Entrementes, pergunta-se em que crê um agnóstico ou ateu como Russell, que dedicou sua vida a refletir e a problematizar a condição humana em suas várias faces? Abaixo, o que destilava com convicção:

O agnóstico não está seguro do que sejam bem e mal quanto certos cristãos. Ele não pensa, como pensava no passado a maioria dos cristãos, que as pessoas que discordam do governo em obtusas questões de teologia devem ser condenadas a uma morte dolorosa. Ele é contra as perseguições e bastante parcimonioso na condenação moral. Pecado, para ele, é uma noção sem serventia. Ele admite, é claro, que certas formas de 
conduta são desejáveis e outras não, mas acredita que a punição das formas indesejáveis só é recomendada quando possui um caráter inibidor ou reformatório, e não quando é infligida por se considerar uma coisa boa em si mesma e que mal deva sofrer. Foi essa crença na punição retaliadora que levou o homem a aceitar o inferno. Esta é a parte do mal causado pela noção de pecado. (RUSSELL, 2000, p.45)

A vida brilhante de Bertrand não ficou ilesa aos ataques do princípio da crueldade religiosa, expressão que o autor cunhou ao aliar religião e crueldade. Esse pensar a humanidade de forma moral e lógica, fora do estatuto religioso, expressa a possibilidade de viver uma vida sem certezas como ele mesmo afirmava (EGNER, 2000, p.8 ): "Nada merece certeza".

\section{A ignorância dos fiéis: o argumento de autoridade com base no princípio da crueldade}

O medo é a base de todo o problema: medo do misterioso, medo da derrota, medo da morte. O medo é progenitor da crueldade, e portanto não é nada surpreendente o fato de a crueldade e a religião andarem lado a lado. (RUSSELL, 2009b, p.40)

A religião cristã, em sua história, sempre se opôs ao pensamento divergente. Foi assim no passado, é assim no presente. Autores como Bertrand Russell, Richard Dalkins, Saramago, San Harris, Comte-Sponville, Denett, entre outros, ao argumentarem sobre o modo de viver sem Deus e sem religião, provocam nas autoridades religiosas e nos fiéis atitudes de conflito que são resolvidas pelo princípio da crueldade, baseado em argumentos emocionais. Pode-se atestar isso com o caso do próprio Russell, que se viu impedido de lecionar na Faculdade de Filosofia Municipal de Nova York, nos anos 40 do século XX.

Bertrand Russell era professor na Universidade da Califórnia e por unanimidade teve recomendação do reitor, do comitê administrativo do Conselho de Educação Superior e do conselho, para ministrar três cursos na Faculdade de Filosofia Municipal de Nova York: Filosofia 13 - Estudo dos conceitos modernos de lógica e de sua relação com a ciência, a matemática e a filosofa; Filosofia 24B - Estudos dos problemas dos fundamentos da matemática; Filosofia 27 - As relações das ciências puras com as aplicadas e a 
influência recíproca entre a metafísica e as teorias científicas. No apêndice ${ }^{1}$ ao livro Por que não sou cristão, atesta-se:

Ninguém com tal fama e distinção comparável jamais havia lecionado na Faculdade Municipal. Quando Bertrand Russell aceitou o convite, Ordway Tead, presidente do conselho, enviou-lhe a carta: Meu caro professor Russell: É com um profundo sentimento que aproveito esta oportunidade para notificá-lo de sua indicação como professor de filosofia da Faculdade Municipal para o período de $1^{\circ}$ de fevereiro a 30 de junho de 1942, em observância à decisão tomada pelo Conselho de Educação Superior em sua reunião do dia 26 de fevereiro de 1940. Sei que sua aceitação desta indicação trará brilho ao nome e às conquistas do Departamento e da faculdade, bem como aprofundará e estenderá o interesse da faculdade pelas bases filosóficas da vida humana. (RUSSELL, 2009a, p.177)

Se houve um reconhecimento da pessoa de Bertrand Russell, quanto ao seu pensamento filosófico e científico, por parte das mentes que compreendem o exercício do livre pensar sem os juízos prévios e os preconceitos, o mesmo não ocorreu por parte do segmento religioso, que tem no argumento de autoridade a base da crueldade. Assim que a indicação do filósofo se tornou pública, o Bispo Manning, da Igreja Episcopal Protestante, reagiu com uma carta que abriu uma campanha de difamação e intimidação a Russell, até chegar a impedi-lo de assumir o curso para o qual fora indicado.

O curioso nessa carta são os argumentos contrários à indicação do professor, que vão de falácias a infantilidades, o que vem corroborar o seu caráter emocional. Esses argumentos, infundados e semelhantes, têm como pano de fundo as injustiças que já se tornaram frequentes na relação entre religião e ciência ao longo da história. A carta dizia:

O que se pode dizer de faculdades e universidades, que afirmam à nossa juventude ser um professor responsável de filosofia [...] um homem que é propagandista reconhecido de um pensamento contrário à religião e à moral, e que especificamente defende o adultério [...]. Será que alguém que se importe com o bem-estar do nosso país estará disposto a ver tais

\footnotetext{
${ }^{1}$ Esse apêndice ao livro Porque não sou cristão, de Bertrand Russell, narra em detalhes esse fato absurdo, ao qual recorremos neste artigo para ilustrar o princípio da crueldade. As referências serão identificadas como apêndice e fazem parte do livro já mencionado.
} 
ensinamentos disseminados com aceitação de nossas faculdades e universidades? Retomando à ofensiva alguns dias depois, o bispo acrescentou: Há aqueles que têm tanta confusão moral e mental que nada veem de errado na indicação [...] de alguém que, em seus escritos publicados, disse que fora dos desejos humanos não existe padrão moral". Deve-se notar, aliás, que, se fosse requisito dos professores de filosofia rejeitar o relativismo ético em suas diversas formas, como o bispo Manning dava a entender, metade ou mais deles teria de ser sumariamente demitida. (RUSSELL, 2009a, p.178)

Vieram à tona várias acusações a Russell, pedidos de revogação do convite, que se somaram a manifestações de jornais eclesiásticos, da editora Hearst e praticamente de todos os políticos democratas e associações religiosas, entre outros. O curioso é que não se fazia referência alguma ao conteúdo que seria ensinado, e sim à pessoa de Russell, fugindo à postura ética que legisla sobre o princípio da liberdade. Em resumo, a exigência de revogação da indicação de Russell era fundamentada em argumentos incompatíveis com a situação, ou seja, argumentos de cunho emocional e moral. Na mídia, nos comícios e discursos, procedia-se à difamação do pensador. O objetivo era condenar o modo de viver e pensar de Russell, o qual, sem a moral religiosa cristã e sem religião, representava uma afronta às personalidades que creem saber o que é melhor para se viver bem e o que deve ser ensinado em suas faculdades.

Essa verticalidade dos fiéis e autoridades eclesiásticas na intolerância ao pensamento diferente demonstra, nesse caso, algo inusitado para pessoas que refletem. A indicação não era para uma cátedra de moral ou de moral religiosa. Além do mais, não estava em jogo a vida do autor e suas demais obras, mas sim sua competência profissional em um determinado ramo do conhecimento. A religião tenta sua manutenção no poder como forma de domínio das consciências: legisla sobre a ação dos indivíduos como se a ela coubesse o monopólio da moral.

Esse evento na vida de Russell serve de alerta em relação à ausência de argumentos racionais por parte das ideologias religiosas. Diversas universidades e intelectuais como Whitehead, Dewey, Shapley, Kasner, Einstein defenderam abertamente sua nomeação, mas de nada adiantou. Einstein observou: "Sempre encontramos forte oposição por parte das mediocridades. Estas não conseguem entender quando um homem conscientemente não se 
submete a preconceitos hereditários, mas usa sua inteligência de maneira honesta e corajosa" (RUSSELL, 2009a, p. 182-183). Também Dewey lamentou o fato: "Só podemos corar de vergonha por essa cicatriz em nossa reputação de fazer jogo limpo". (RUSSELL, 2009a, p.216). Na faculdade para a qual fora nomeado, professores e estudantes se mostravam insatisfeitos ante a repercussão dessa intervenção eclesiástica e política em assuntos internos. É interessante notar que

os pais dos alunos da Faculdade Municipal também não se alarmaram ante a perspectiva de que seus filhos fossem expostos à influência corrosiva da mente superior por trás do amor livre, apesar da maior parte dos opositores de Russell desfilar como porta-voz dos pais-ofendidos. A Associação de Pais da Faculdade Municipal votou unanimemente a favor da ação do Conselho. (RUSSELL, 2009a, p.184)

O fato é que Russel não pôde assumir o cargo para o qual fora indicado. O caso foi assumindo proporções inesperadas, com declarações e acusações infundadas. As manobras para que ele não assumisse beiraram o ridículo, como no caso da Sra. Jean Kay:

Ela preencheu um formulário de queixa de contribuinte na Suprema Corte de Nova York para invalidar a nomeação de Russell, sob a alegação de ele ser estrangeiro e defensor da imoralidade sexual. Ela se declarou pessoalmente preocupada com o que poderia acontecer à sua filha Glória ${ }^{2}$, caso se formasse aluna de Bertrand Russell. Os advogados da Sra. Kay apresentaram outras duas razões para barrar Bertrand Russell. Por um lado, ele não fora testado quanto à sua competência e por outro, era contrário à política pública indicar como professor qualquer pessoa que acreditasse no ateísmo. (RUSSELL, 2009a, p.186)

O caso de Russell, que tomou um rumo inusitado, com distorções tanto no campo jurídico quanto no direito à liberdade de ação, é uma evidência de como o princípio da crueldade age em prol de um fundamentalismo obscurantista. As acusações infundadas que o impediram de assumir a cátedra levaram Dewey a afirmar:

\footnotetext{
${ }^{2}$ O apêndice (RUSSELL, 2009a, p.177) explica que “ na época em que Bertrand Russell foi nomeado,apenas homens podiam assistir a cursos diurnos em matérias de artes liberais na Faculdade Municipal".
} 
As pessoas, se é que existem, que recorrem aos escritos do Sr. Russell em busca de imundice e obscenidade, ficarão decepcionadas. Essas coisas estão tão ausentes que a maneira moralmente destemperada e irresponsável que estão sendo atribuídas a Russel é razão bastante para acreditar que aqueles que o fazem têm visão tão autoritária da moral que suprimiriam, se tivessem poder para isso, toda a discussão crítica das crenças e práticas que desejam impor aos outros. (RUSSEL, 2009a, p.195)

Como reagiu Russell frente a esse processo injusto e de condução questionável? Sua atitude foi notável e digna de elogios, o que denota a sabedoria de não se igualar aos cristãos quando a situação é de conflito, e não de diálogo. Após a indicação e as várias acusações à sua pessoa, ele se abstivera de fazer comentários; por fim, fez uma breve declaração:

Não tenho desejo de responder ao ataque do bispo Manning [...]. Qualquer pessoa que na juventude decida tanto falar quanto pensar com honestidade, independentemente da hostilidade e das interpretações errôneas, espera tais ataques e logo aprende que é melhor ignorá-los". (RUSSEL, 2009a, p.187)

Somente quando o caso foi ao tribunal de justiça, Russell se viu obrigado a se defender, pois a mentira lhe ferira a honra:

Até agora, mantive um silêncio quase ininterrupto a respeito da controvérsia relativa à minha indicação à Faculdade Municipal, [...] porque não pude admitir que minhas opiniões fossem relevantes. Mas, quando afirmações grosseiramente mentirosas a respeito de minhas ações são feitas em juízo, sinto que devo apresentar a minha versão. (RUSSELL, 2009a, p.187)

Russel foi lapidar ao mostrar em seus argumentos de que maneira a invenção de uma mentira se torna um instrumento de poder e difamação. Ante a afirmação do Times de que ele "deveria ter demonstrado a sabedoria de recusar a indicação assim que seus resultados danosos se tornaram evidentes", ele rebateu: 
Espero que me permitam comentar as referências feitas por este jornal à controvérsia originada pela minha indicação à Faculdade Municipal de Nova York e, particularmente, a respeito da opinião de que eu "deveria ter demonstrado a sabedoria de recusar [...] assim que seus resultados danosos se tornaram evidentes". Em certo sentido, essa teria sido a atitude mais sábia. Certamente teria sido bem mais prudente, na medida em que se consideram meus interesses pessoais, e muito mais agradável. Se eu tivesse considerado meus próprios interesses e inclinações, deveria ter me retirado imediatamente. Mas, por mais prudente que tal ação pudesse ter sido do ponto de vista pessoal, também teria sido, a meu ver, um ato covarde e egoísta. Um grande número de pessoas que perceberam que seus próprios interesses e os princípios da tolerância e da liberdade de expressão estavam sendo ameaçados ficaram ansiosas, desde o início, para dar continuidade à controvérsia. Se eu tivesse me retirado, teria privado essas pessoas de seu casus belli e teria aceitado tacitamente a proposta da oposição de que grupos importantes devem ter permissão de afastar de cargos públicos pessoas cujas opiniões, raça ou nacionalidade julguem repugnantes. Isso pareceria imoral... Não acredito que, de maneira geral, a controvérsia seja danosa. Não são as controvérsias e as diferenças abertas que ameaçam a democracia. Ao contrário, essas são suas maiores salvaguardas. É parte essencial da democracia que grupos importantes, mesmo que sejam e por mais que sintam seus sentimentos ultrajados. Em uma democracia, é necessário que as pessoas aprendam a suportar que seus sentimentos sejam ultrajados. (RUSSELL, 2009a, p.212-213).

Esse fato ocorrido na vida de Russell ilustra bem a discussão proposta em relação ao princípio da crueldade e ao mesmo tempo evidencia em que sentido a relação entre ciência e religião se baseia no conflito, e não no diálogo. Por ignorância, os crentes fazem acusações sem conhecimento de causa, usam argumentos emocionais para legitimar uma certeza inexistente e, por medo de se convencerem de uma verdade provisória, são cruéis em seus métodos para defender a fé.

\section{Considerações finais}

A vida possível para o ateu é aquela em que os argumentos racionais, que interagem no campo da liberdade, da democracia, são respeitados numa relação ética em que se permite a diferença de ideias. Não é necessário propagar o que não se vive. É fundamental, ao se viver de acordo com suas escolhas sem a culpa imposta pelas religiões, aprender com o conflito e assumir que a verdade provisória é criação nossa e nos faz viver bem. Frente a 
fundamentalismos, não há argumentos racionais, pois não se configura o campo aberto a discussões intelectuais em busca de uma verdade e de análises científicas, e sim ao emocionalismo dos que estão cegos a argumentos, convencidos da ilusão a que são submetidos.

As religiões professam o que não conseguem sustentar. A certeza da existência de Deus e do plano divino se justifica a partir de argumentos emocionais que, na maioria das vezes, conduzem ao princípio da crueldade, gerando violência, conforme conhecemos na história e, particularmente, no caso de Bertrand Russell.

Não há garantias de que outras violências não venham a acontecer. As certezas estão por toda a parte e elas são fundadas no princípio da crueldade associado ao medo de descobrir que é possível viver bem sem crer em Deus e sem estar vinculado aos dogmas religiosos. Os ateus e agnósticos, que buscam argumentos racionais e, em seu modo de viver, aspiram à felicidade para todos, são as vítimas preferidas dos argumentos emocionais e do exercício da crueldade.

\section{Referências}

EGNER, Robert. O melhor de Bertrand Russell - silhuetas satíricas. Rio de Janeiro, Bertrand Brasil, 2000.

RUSSELL, Bertrand. Por que não sou cristão. Porto Alegre: L\&M, 2009a.

RUSSELL, Bertrand. Religião e ciência. Ribeirão Preto: FUNPEC, 2009b.

RUSSELL, Bertrand. No que acredito. Porto Alegre: L\&M, 2007. 